\title{
Alkol ve sigara kullanımının infertil erkeklerde semen parametreleri üzerine etkisinin araștırılması
}

\author{
Investigation of the effects of alcohol and tobacco use on semen \\ parameters in infertile men
}

\author{
Göksun Demirel'®, Tulay Irez²®
}

\section{öz}

AMAÇ: Üreme çağındaki çiftlerin \%15'ini etkileyen infertilite; 12 ay ve daha uzun süreli korunmasız cinsel ilişkiye rağmen gebelik oluşmaması durumudur. Tüm infertil olguların yarısından erkek infertilitesinin sorumlu olduğu bilinmektedir. Günümüzde değişen yaşam şartları ile infertilite görülme sıklığının son 50 yılda $\% 30$ oranında arttığı ve sperm konsantrasyonunun $\% 50$ oranında azaldığı bilinmektedir. Yapılan retrospektif çalışma ile infertil erkeklerde alkol ve sigara kullanımına bağlı olarak semen analiz sonuçlarının değerlendirilmesi ve fertilizasyon bașarısı için yol gösterici etkilerinin belirlenmesi amaçlanmıştır.

GEREÇ VE YÖNTEM: Çalışmamız kapsamında en yaygın sağlığa zararlı alışkanlıklardan ikisi olan sigara ve alkol bağımlılığı ve bunların erkek infertilitesine etkileri üzerine retrospektif bir araştırma gerçekleştirilmiştir. Tütün içimi dünyada oldukça yaygındır; üreme ve cinsel fonksiyon üzerinde iyi bilinen yan etkiler göz önüne alındığında ciddi bir sağlık problemidir. Alkol tüketimi sıklıkla sosyal olarak kabul edilebilir olarak düşünülmektedir ancak gonadal fonksiyonun olumsuz etkileri son yıllarda sıklıkla rapor edilmektedir. Bu çalıșmada infertilite tedavisi için Biruni Üniversitesine başvuran 426 infertil erkek hastanın alkol ve sigara tüketimi ile semen kalitesi arasındaki ilişki semen analizlerinden elde edilen verilerin istatistiksel analiz yöntemleriyle saptanmıştır. Çalışmamız bağımsız iki grup ortalamasını test eden Student $t$ testi ile karşılaştırılmıștır.

BULGULAR: Alkol ve sigara kullanan bireylerin FSH miktarlarının, alkol ve sigara kullanmayan bireylere göre anlamlı azalış gösterdiği ve sperm motilitesinde alkol ve sigara kullanıcılarında anlamlı bir azalıs tespit edilmiştir. Yıkama sonrası sperm sayılarında alkol ve sigara kullanıcılarında dramatik bir azalıș belirlenirken sadece sigara kullanıcısı olan bireylerin semen analizleri değerlendirildiğinde özellikle sperm hızının anlamlı bir şekilde düştüğü gösterilmiştir.

SONUC̦: Sonuçlarımız sigara kullanımının semen hacmi üzerinde anlamlı bir azalma meydana getirdiğini göstermektedir. Bu çalışmadan elde edilen veriler ışı̆̆ında, alkol ve sigaranın kısa süreli etkilerinin özellikle sperm fonksiyonları üzerinde olduğu anlaşılmıştır. Bu çalışmanın sonucunda elde edilen verilerin, daha fazla örnekle yapılacak daha kapsamlı çalışmalara zemin oluşturacağına inanmaktayız.

Anahtar Kelimeler: Alkol bağımlılığı, sigara bağımlılığı, erkek infertilitesi

\section{ABSTRACT}

OBJECTIVES: Infertility is the inability to conceive after a 12 months and longer of having unprotected intercourse and it affects $15 \%$ of couples who are in their reproductive ages. Male infertility is responsible for half of all infertile patients. It is know that over the past 50 years infertility rate has increased by $30 \%$ and human sperm concentration showed a $50 \%$ decrease. The aim of this retrospective study was to evaluate the results of semen analysis and to determine the guiding effects of fertilization for alcohol and tobacco use in infertile males.

MATRERIAL AND METHOD: We performed a retrospective study on two of the most common unhealthy habits tobacco and alcohol addiction, and their effects on male fertility Tobacco smoking is remarkably common in the world; a wide health problem, given the well-known ill-effects on reproductive and sexual function. Alcohol consumption is frequently noted socially acceptable, but its negative effects of gonadal function have been systematically reported in the last years. Alcohol consumption is often considered socially acceptable, but negative effects of gonadal function are frequently reported in recent years. In this study, the relationship between alcohol and cigarette consumption and semen quality of 426 infertile male patients who applied to Biruni University for infertility treatment was determined by statistical analysis methods of syllable analysis. Our study was compared with the Student t test, which tested the independent two-group averages.

RESULTS: The levels of FSH in alcohol and cigarette users were significantly lower than those in smokers and non-smokers, and sperm motility was significantly decreased in smokers and smokers. A dramatic decrease in alcohol and smokers was observed in sperm counts after washing, but it was shown that especially sperm rates of smokers decreased significantly only when the semen analysis of individuals who were smoking users were evaluated.

CONCLUSION: Our results show that smoking caused a significant decrease on semen volume. In the light of the data obtained from this study, it was understood that the short-term effects of alcohol and smoking were especially on sperm functions. We believe that the data obtained as a result of this study will provide a basis for more comprehensive studies with more examples.

Keywords: Alcohol dependence, tobacco addiction, male infertility

\section{GENEL BILGILER}

Dünya Sağlık Örgütü’ne göre infertilite; 12 ay veya daha uzun süre ile düzenli korunmasız cinsel ilişki sonrasında gebelik elde edememe durumu olarak bildirilmiştir buna bağlı olarak bir yıl boyunca korunmadan ilişkiye giren çiftlerin yaklaşık olarak yüzde 15 'i çocuk sahibi olamamaktadır. ${ }^{[1]}$ 
Günümüzde erkek fertilitesi üzerinde görülen azalma oranı dikkat çekmektedir, son 35 yılda düzenli bir şekilde sperm konsantrasyonunun azaldığı gösterilmiştir. ${ }^{[2]}$

Sperm kalitesinin azalmasına sebep olan birçok faktör olduğu bilinmektedir. Gelişen sanayileşmeye, artan nüfusun ihtiyaçlarına, değişen yaşam stillerinin gereksinimlerine bağlı olarak maruz kalınan toksik madde miktarı gün geçtikçe artmakta ve kullanım alanı yaygınlaşan her bir toksik madde ekolojik sistemin bütün basamaklarını etkilemektedir. Tehlikeli ajanların varlığı erkek üreme sistemindeki hataların oluşumuna sebebiyet veren önemli etkenlerdendir. ${ }^{[3]}$

Yapılan çalışmalar, çevresel faktörlerin ve yaşam tarzının fertilite üzerindeki potansiyel etkisine olan ilgiyi yeniden gündeme getirmektedir: erkek infertilitesinin sosyal maliyetlerini ve bunun sonucunda halk sağlığına getirdiği yükleri azaltmak için, önlenebilir faktörlerin belirlenmesi çok önemlidir. ${ }^{[4]}$

Sigara ve alkol tüketiminin genel sağlık üzerindeki rolü evrensel olarak kabul edilmektedir, ancak erkek infertilitesi üzerindeki etkileri daha az bilinmektedir ve erkek üreme sağlığı, kirliliğin ve çevresel risklerin hassas bir göstergesi olarak düşünülebilmektedir. ${ }^{[5]}$

Bulaşıcı olmayan hastalıkların \%60'ından fazlası sigarayı risk faktörleri arasında listelemektedir ve her yıl altı milyondan fazla ölüm tütün tüketimi ve pasif içicilikten kaynaklanmaktadır. ${ }^{[6]}$ Zararlı etkilerini destekleyen kanıtların artmasına rağmen, Dünya Sağlik Örgütü’nün son raporlarının da gösterdiği gibi, sigara kullanımı hala yaygın durumda seyreden bir bağımlılık türüdür. Dünyadaki tüm yetişkin erkeklerin üçte birinden fazlası tütün ürünleri kullanmaktadır benzer şekilde, üreme çağındaki kadınların yaklaşık \%30'u sigara kullanmaktadır. ${ }^{[7]}$

Klinik ve deneysel çalışmalar alkol tüketimini erkek infertilitesi için potansiyel bir risk faktörü olarak incelemiş, hem testosteron metabolizması hem de spermatogenez üzerinde doğrudan bir etki yaptığını göstermiştir. ${ }^{[8]}$

Etik nedenlerden dolayı, tütün kullanımı, eğlence amaçlı uyuşturucu kullanımı ve alkol tüketiminin etkileriyle ilgili girişimsel çalışmalar insanlarda genellikle mümkün değildir. Kısmi bir çözüm hayvan çalışmalarından gelmektedir; ancak bu modellerde maruz kalma insanlara göre belirgin olarak daha yüksektir ve bu nedenle sonuçlar dikkatle yorumlanmalıdır. Bu nedenle bu konulardaki çalışmaların büyük kısmı uygulama kayıtlarından geriye dönük olarak gerçekleştirilmektedir. ${ }^{[9]}$

Bu çalışmada sigara ve alkolün birlikte kullanımının, infertilite tedavisi için başvuran bireylerin semen parametreleri üzerinde gösterdiği etkiyi retrospektif olarak göstermek amaçlanmıştır.

\section{GEREÇ VE YÖNTEM}

Çalışmamız için Biruni Üniversitesi Girişimsel Olmayan Araştırmalar Etik Kurulundan 2017/5-4 karar nolu "Etik Kurul Onayı" alındı. Biruni Üniversitesi Hastanesine 2016-2018 yılları arasında infertilite tedavisi için başvuran 426 hastanın kayıtları retrospektif olarak değerlendirildi. Hastalardan; eşi normal olduğu halde, normal sıklıkta ve korunmaksızın cinsel ilişki sonucu bir yıl içinde çocuk sahibi olamayan erkeklerden, herhangi bir kronik hastalığ 1 olmayan, ek ilaç yada uyuşturucu madde kullanmayan intrauterin inseminasyon (İUI) infertilite tedavi endikasyonuna sahip olan 20-50 yaş arası bireyler çalışmaya dahil edildi. Bireylerin sigara kullanımı ve alkol kullanımı özellikle takip edilmiş sadece sigara kullanan, hem sigara hem alkol kullanan ve her ikisini de kullanmayan bireyler belirlendi. Tüm hastaların androlojik ve ayrıntılı fizik muayenesi, biyokimyasal testleri ve semen analizi Biruni Üniversitesi Hastanesinde gerçekleştirildi. Karyotip anomalisi, Y kromozom mikrodelesyonu ve vasdeferens ve/veya seminal vezikül yokluğu olan hastalar çalışma dışı bırakıldı. En az 1 yıldır günde 10 ila 20 adet sigara ve yine en az 1 yıldır günde 2 ila daha fazla kadeh alkol kullanan bireyler aynı yaş grubundaki sigara ve alkol kullanım öyküsü bulunmayan bireyler ile karşılaştırıldı. Hastalardan elde edilen semen örnekleri 37 C derece sıcaklıkta bekletildi ve motilite yani hareketlilik değerlendirmesi ejakulasyonu takiben 1 saat içinde oda sıcaklığında gerçekleştirildi. Semen örneklerine ait sperm miktarı ve hareketli sperm yüzdesi 40x objektif ile ışı mikroskobu kullanılarak belirlendi. Çalışmamız kapsamında sigara ve alkol kullanan ve kullanmayan bireylerin primer-sekonder infertilite dağılımı, varikosel görülüp görülmemesi, FSH değerleri, sperm sayısı, sperm hacmi, sperm hareketliliği, yıkama sonrası sperm sayıları, lökosit miktarları gibi değişkenleri Statistical Package for Social Sciences 15,0 (SPSS 15,0) programı kullanılarak karşılaştırıldı. Çalışma verileri değerlendirilirken tanımlayıcı istatistiksel yöntemlerin (Ortalama, Standart sapma) yanı sıra niceliksel verilerin karşılaştırılmasında normal dağılım gösteren parametrelerin gruplar arası karşılaştırmalarında Student's t-test kullanıldı. Sonuçlar \%95'lik güven aralığında, anlamlılık $\mathrm{p} \leq 0,05$ düzeyinde değerlendirildi.

\section{BULGULAR}

426 infertil bireyden oluşan çalışma grubumuzda 136 erkek bireyin sigara kullanıcısı, 36 bireyin ise düzenli olarak hem alkol hem de sigara kullanmakta olduğu gösterilmiştir. Çalışma grubumuzun yaş ortalası 33,44 4 ,65 olarak saptanmıştı. Sigara ve alkol kullanımına bağlı gruplar arasında anlamlı bir yaş farkı saptanmamıştır $(\mathrm{p}=0,745)$. Çalışmaya dahil edilen bireylerin sigara ve alkol kullanımına bağlı olarak primer ve sekonder infertilite dağılımında $(\mathrm{p}=0,932)$ (Tablo 1) ve varikosel görülme oranı (Tablo 2) arasında anlamlı bir fark bulunmamıştır. 
Tablo 1. Alkol ve sigara kullanımına bağlı primer ve sekonder infertilite dağılımı

\begin{tabular}{lcc}
\hline Infertilite Çeşidi & $\begin{array}{c}\text { Primer } \\
\text { infertilite }\end{array}$ & $\begin{array}{c}\text { Sekonder } \\
\text { infertilite }\end{array}$ \\
\hline Alkol ve sigara kullananlar & $\% 75$ & $\% 25$ \\
Alkol ve sigara kullanmayanlar & $\% 75,8$ & $\% 24,2$ \\
\hline
\end{tabular}

$\mathrm{X}^{2}=0,007 \mathrm{p}=0,932$

Tablo 2. Alkol ve sigara kullanıcılarının varikosel dağılımı

\begin{tabular}{lcc}
\hline Varikosel Dağııımı & Var & Yok \\
\hline Alkol ve sigara kullananlar & $\% 5,6$ & $\% 94,4$ \\
Alkol ve sigara kullanmayanlar & $\% 15,8$ & $\% 84,2$ \\
\hline
\end{tabular}

$x^{2}=3,133 p=0,077$

Çalışmamız kapsamında alkol ile sigara kullanan ve her ikisini de kullanım öyküsü bulunmayan bireylerin FSH değerleri, sperm sayısı, sperm hacmi, sperm hareketliliği, yıkama sonrası sperm sayıları, lökosit miktarları gibi değişkenleri ile ilgili ortalama ve standart sapma değerleri bağımsız iki grup ortalamasını test eden Student t testi ile karşılaşıtırılarak, farkllı̆ğın istatistiksel olarak önemli bulunan değişkenleri sırasıyla FSH $(\mathrm{p}=0,012)$ sperm hızı $(\mathrm{p}=0,047)$ ve YKS (yıkama sonrası sperm sayısı) $(\mathrm{p}=0,01)$ olarak belirlenmiştir. Diğer değişken ortalamalarının arasında farklılılığın önemli olmadığı bulunmuştur ( $p>0,05)$ (Tablo 3).

Olguların kromatin kondansasyonu değerleri incelendiğinde alkol ve sigara kullanımının kromatin kondansasyonu üzerinde negatif etki yaptığı görülmektedir ( $\mathrm{p}=0,013$, $\mathrm{p}=0,033)$ (Tablo 3 ve 4).

Sadece sigara kullanan ve sigara kullanım öyküsü bulunmayan bireyler arasında ise farklılığın istatistiksel olarak önemli bulunan değişkeni semen hacmi $(\mathrm{p}=0,012)$ olarak bulunmuştur. Diğer değişken ortalamalarının arasında farklılılığın önemli olmadığı gösterilmiştir ( $>0,05)$. (Tablo 4).

Tablo 3. Alkol ve sigara kullanıcılarına ait sperm parametreleri değişimleri

\begin{tabular}{lcccc}
\hline Alkol ve Sigara Kullanımı & Var $X \pm S D$ & Yok $X \pm S D$ & $t$ & 0,653 \\
\hline Alkol ve sigara kullanım süresi (ay) & $14,00 \pm 4,60$ & $16,20 \pm 3,20$ & 0,448 & $0,012 *$ \\
FSH & $7,050 \pm 3,380$ & $5,87 \pm 2,00$ & 2,524 & 0,673 \\
Sperm konsantrasyonu Mil/mI & $17,67 \pm 15,23$ & $20,34 \pm 18,27$ & 0,467 & 0,972 \\
Semen hacmi & $3,282 \pm 1,859$ & $3,269 \pm 2,169$ & 0,036 & $0,047 *$ \\
Hızlı (\%) & $22,424 \pm 16,530$ & $28,371 \pm 19,392$ & 1,995 & 0,783 \\
Yavaş (\%) & $5,914 \pm 2,737$ & $6,152 \pm 5,019$ & $-0,276$ & 0,582 \\
Yerinde hareketli (\%) & $2,963 \pm 2,261$ & $2,721 \pm 2,129$ & 0,551 & 0,70 \\
Duran (\%) & $63,571 \pm 19,835$ & $69,435 \pm 18,007$ & $-1,819$ & 0,654 \\
Normal (\%) & $3,882 \pm 2,590$ & $3,381 \pm 6,450$ & 0,449 & 0,363 \\
Baş anomalisi (\%) & $83,764 \pm 5,527$ & $81,950 \pm 11,463$ & 0,912 & 0,331 \\
Boyun anomalisi (\%) & $6,088 \pm 3,423$ & $7,413 \pm 7,849$ & $-0,974$ & 0,240 \\
Kuyruk (\%) & $6,264 \pm 3,165$ & $7,419 \pm 5,625$ & $-1,117$ & $0,01 *$ \\
Yıkama sonrası hareketli sperm sayısı & $1,663 \pm 0,515$ & $2,030 \pm 1,131$ & 3,371 & 0,756 \\
Lökosit & 2,000 & $2,862 \pm 2,702$ & $-0,314$ & 0,013 \\
Kromatin kondansasyonu (AB negatif \%) & $21,25 \pm 9,61$ & $27,65 \pm 8,35$ & 2,654 & \\
\hline
\end{tabular}

Tablo 4. Sigara kullanıcılarına ait sperm parametreleri değişimleri

\begin{tabular}{|c|c|c|c|c|}
\hline Sigara kullanımı & $\begin{array}{l}\text { Sigara kullanan } \\
\qquad X \pm S D\end{array}$ & $\begin{array}{c}\text { Sigara kullanmayan } \\
\qquad X \pm S D\end{array}$ & $t$ & $p$ \\
\hline Sigara kullanm süresi (ay) & $15,23 \pm 2,1$ & $14,3 \pm 0,25$ & 1,987 & 0,195 \\
\hline FSH & $5,919 \pm 2,195$ & $6,004 \pm 2,137$ & 0,335 & 0,738 \\
\hline Sperm konsantrasyonu (mil/ml) & $25,35 \pm 17,23$ & $27,38 \pm 19,29$ & 0,086 & 0,679 \\
\hline Semen hacmi (ml) & $3,022 \pm 1,702$ & $3,966 \pm 1,863$ & 2,782 & $0,012 * *$ \\
\hline Hızlı (\%) & $21,264 \pm 14,031$ & $24,540 \pm 14,237$ & 2,211 & 0,22 \\
\hline Yavaş (\%) & $6,130 \pm 5,456$ & $6,130 \pm 4,332$ & $-0,001$ & 0,999 \\
\hline Yerinde hareketli (\%) & $2,763 \pm 2,162$ & $2,736 \pm 2,130$ & 0,098 & 0,922 \\
\hline Duran (\%) & $70,311 \pm 16,146$ & $67,7804 \pm 19,698$ & 1,353 & 0,177 \\
\hline Normal (\%) & $2,698 \pm 2,779$ & $4,024 \pm 7,937$ & 2,070 & 0,39 \\
\hline Baş (\%) & $82,952 \pm 9,308$ & $81,427 \pm 12,300$ & 1,330 & 0,184 \\
\hline Boyun (\%) & $6,929 \pm 5,005$ & $7,592 \pm 9,143$ & 0,845 & 0,395 \\
\hline Kuyruk (\%) & $7,349 \pm 5,690$ & $7,286 \pm 5,269$ & 0,111 & 0,912 \\
\hline YKS (milyon) & $1,732 \pm 0,521$ & $1,668 \pm 0,662$ & 1,015 & 0,311 \\
\hline Lökosit (mil/ml) & $2,846 \pm 2,609$ & $2,823 \pm 2,777$ & 0,023 & 0,982 \\
\hline Kromatin kondansasyonu $\mathrm{AB}$ negatif \% & $18,28 \pm 7,98$ & $27,22 \pm 9,33$ & 2,986 & 0,032 \\
\hline
\end{tabular}




\section{TARTIȘMA}

Çalışmamızda yaklaşık olarak 1-2 yıl süresince alkol veya sigaranın kullanışının semen volümü, sperm motilitesi ve kromatin kondansasyonu ve hazırlanmış sperm sayısı üzerine negatif etki yaptığı anlaşılmıştır. Bu etkilerin erken dönemde bile sperm fizyolojisi üzerinde toksik etki oluşturabildiği anlaşılmıştır.

Alkol ve fertilite arasındaki bağlantı 1985 yılında ilk kez araştırılmış seminal sıvı örneklerinin analizi ve alkol ba$\breve{g} ı$ lmllığı sendromlu 20 erkeğin hormonal değerlendirmesi, kronik alkoliklerde testosteron düzeylerinin, seminal sıvı hacminin ve sperm konsantrasyonunun kontrollere göre anlamlı düzeyde azaldığını gösterilmiştir. ${ }^{[10]}$

Daha sonra, prospektif otopsi çalışmasında, ağır alkol içicilerin önemli bir yüzdesinin tam spermatogenik arrest olduğu ve ağır içicilerin ortalama testiküler ağırlığının kontrollerle karşılaştırıldığında hafif fakat anlamlı derecede düşük olduğu gösterilmiştir. ${ }^{[11]} 2005$ yllında Muthusami ve ark., kronik alkoliklerde FSH, LH ve E2 düzeylerinde anlamlı bir artış saptarken, testosteron düzeylerinin anlamlı olarak azaldığını bildirmişlerdir. Aynı çalışmanın sonuçlarında semen hacmi, sperm sayısı, motilite ve morfolojik olarak normal sperm sayısının anlamlı olarak azaldığı bildirilmiştir. ${ }^{[12]} 2011$ yılında 57 çalışma ve 29,914 denek içeren bir meta-analizde alkol ile sperm hacmi, sperm morfolojisi ve sperm motilitesi arasında anlamlı bir ilişki bulunmuştur. ${ }^{[13]}$

Jensen ve ark. 8344 sağlıklı erkekte, orta derecede alkol alımının (medyan haftalık alım 8 ünite), sağlıklı erkeklerde semen kalitesi ile ters orantılı olmadığı, daha yüksek serum testosteron düzeyleri ile ilişkili olduğunu öne sürmüştür. ${ }^{[14]}$ Ayrıca, kronik alkol tüketimi, doğurganlığı akut alkol tüketiminden daha fazla etkilemektedir. Hansen ve ark. 347 erkek arasında kesitsel bir çalışmada alkol alımı, semen kalitesi ve üreme hormonlarının son 5 günü arasındaki ilişkiyi değerlendirdiği çalışmada alkol alımının genelde semen karakteristiğinin bozulmasıyla ilişkili, ancak tutarlı bir doz yanıtı paterni olmadığını bildirimiştir. ${ }^{[9]}$ Beş gün içinde daha yüksek alkol alımında daha düşük sperma özelliklerine ve daha yüksek östradiol/testosteron oranına doğru bir hormonal kayma eğilimi olduğunu göstermiştir. Alkol tüketiminin zamanlamasının önemi de Condorelli ve ark. Tarafından ılımlı alkol kullananların sperma ve hormonal parametrelerini retrospektif olarak değerlendirmiş ve ara sıra içenleri günlük içenler ile karşılaştırdıkları çalışmalarının sonucunda, "günlük içiciler" grubuna giren infertil hastaların semen kalitesi ve hormonal özellikleri diğer gruplara göre anlamlı olarak daha kötü bulunmuştur. ${ }^{[15]}$

Sigara kullanmanın sperm kreatin kinaz aktivitesini azaltmakta olduğu ve buna bağlı olarak sperm motilitesini ve enerji homeostazisini bozduğu gösterilmiştir. ${ }^{[16]}$ İn vitro çalışmalar dâhilinde, olası sorumlu faktörler olarak nikotin, kotinin ve kadmiyum olarak göstermiştir; in vivo olarak, hem sigara içme süresi hem de günde sigara içilen sigara miktarının, sperm içindeki kreatin kinaz aktivitesini azaltabildiği bildirilmiştir. ${ }^{[1]]}$ Sigara içmenin intrauterin inseminasyon sonuçlarını olumsuz etkilediği ve sperm kromatin kondansasyon oranını düşürdüğü gösterilmiştir. ${ }^{[18]}$ Çalışmamızda da diğer semen parametrelerinde farklılık gözlenmediği halde sigara, veya sigara ve alkol'ün birlikte kullanılması durumunda sperm kromatin kondansasyonunda azalma gözlenmiştir.

Yakın zamanda yapılan genom çalışmaları, sigara içenlerde 95 bölgenin metilasyon profilinde değişiklikler olduğunu ortaya koymuştur. ${ }^{[19]}$ Sigara ile ilgili DNA hasarı ve metilasyon paternleri, dolaylı sistemik maruziyet nedeniyle direkt olarak maruz kalmayanlar bireylerin bazı dokularında gözlenmiştir. ${ }^{[20]}$ DNA adduktları ve DNA hasarı sperm parametreleriyle, çoğunlukla konsantrasyon ve motilite ile ters orantilıdır ve her ikisi de ovum tarafindan tamir edilme şansı az olan zigota gönderilmektedir. ${ }^{[21]}$ Sperm DNA fragmantasyonu ayrıca artmış spontan abortus oranları ile bağlantılıdır ve bu nedenle yardımcı üreme teknikleri uygulanan deneklerde dikkatle değerlendirilmelidir. ${ }^{[22]}$ Tütün tüketiminden kaynaklanan oksidatif DNA hasarının ve daha yüksek kadmiyum seviyelerinin benzer şekilde doğurganlık ile ilişkili olduğu gösterilmiştir. ${ }^{[23]}$

Sigara ve alkol bağımlılı̆̆ının insan sağlığı ve üzerine bilinen birçok olumsuz etkisi bulunmaktadır. Günümüzde artış gösteren bağımlılık türlerinin fertilite üzerinde negatif etkiler yarattığ $ı$ bilinmektedir. Dünya üzereninde en yaygın kullanılan ve erişimi en kolay gerçekleşen tütün ürünlerinden sigaranın gerek tek başına kullanımı gerek alkol kullanımına eşlik etmesi sonucu semen analizinde kullanılan parametrelerde değişiklik yarattığı düşünülmektedir. Akut ve kronik alkol kullanımının farelerde hipotalamik eksen üzerine negatif etkileri gösterilmiştir. ${ }^{[24,25]}$ Zakarya Bani Meri ve arkadaşları 2013 de yaptıkları çalışmada sigara kullanımının seminal parametreler üzerinde özellikle semen hacmi ve sperm motilitesi üzerine negatif etkilerini göstermişlerdir. ${ }^{[26]}$

Araştırmamız boyunca; infertilite tedavisi için başvuran çiftlerden erkek bireylere ait yaş, vücut kütle indeksi, infertilite süresi ve şekli, sigara ve alkol kullanımı ile ilgili bilgiler taranırken, erkek bireylerin varikosel öyküsü, kronik rahatsızlıkları ve geçirdiği operasyonlar kayıt altına alındı. Üroloji konsültasyonu yapılarak hormonal değerlendirme, sperm sayısı, hacmi, motilitesi gibi semen analizi parametreleri değerlendildi. Bu veriler kapsamında; alkol ve sigara kullanıcısı bireyler ile alkol ve sigara kullanıcısı olmayan bireyler arasında FSH, sperm hızı ve YKS arasında istatistiksel anlamlı bir ilişki saptandı. Sonuçlarımız alkol ve sigara birlikte kullanımının FSH değerinde artı̧̧a, sperm hızı, YKS üzerinde anlamlı şekilde azalmaya neden olduğunu kanıtlamaktadır. Sadece 
sigara kullanan bireyler ile sigara kullanıcısı olmayan bireyler arasında semen hacmi üzerinde istatistiksel olarak anlamlı bir değişiklik olduğu görüldü. Sonuçlarımız sigara kullanımının semen hacmi üzerinde anlamlı bir azalma meydana getirdiğini göstermektedir. Bu çalışmadan elde edilen veriler ışı̆̆ında, alkol ve sigaranın kısa süreli etkilerinin özellikle sperm fonksiyonları üzerinde ve kromatin yapısında bulunduğu anlaşılmıştır. Bir sonraki aşamada, aynı parametrelerin farklı protokollerdeki ilişkisi karşılaştırılabilir. Bu çalışmanın sonucunda elde edilen verilerin, daha fazla örnekle yapılacak daha kapsamlı çalışmalara zemin oluşturacağına inanmaktayız.

\section{Etik Kurul Onayı}

Çalışma, Biruni Üniversitesi Girişimsel Olmayan Araştırmalar Etik Kurulu tarafından onaylandı (onay tarihi ve sayısı: 2017/5-4).

\section{Hakem Değerlendirmesi}

Dış bağımsız.

\section{Çıkar Çatışması}

Yazarlar çıkar iliş̧kisi olmadığını beyan etmişlerdir.

\section{Finansal Destek}

Herhangi bir mali destek alınmamıştır.

\section{Ethics Committee Approva}

The study was approved by Biruni University Non-Interventional Research Ethics

Committee. (date and number of approval: 2017/5-4).

\section{Peer-review}

Externally peer-reviewed.

\section{Conflict of Interest}

No conflict of interest was declared by the authors.

\section{Financial Disclosure}

No financial support has been received.

\section{KAYNAKLAR}

1. Zegers-Hochschild F, Adamson GD, de Mouzon J, Ishihara O, Mansour R, Nygren K, et al. International Committee for Monitoring Assisted Reproductive Technology (ICMART) and the World Health Organization (WHO) revised glossary of ART terminology, 2009. Fertil Steril 2009;92:1520-4. [CrossRef]

2. Howards SS. Treatment of male infertility. N Engl J Med 1995;332:312-7. [CrossRef]

3. Sharpe RM. Environment, lifestyle and male infertility. Baillieres Best Pract Res Clin Endocrinol Metab 2000;14:489-503. [CrossRef]

4. Baska KM, Manandhar G, Feng D, Agca Y, Tengowski MW, Sutovsky M, et al. Mechanism of extracellular ubiquitination in the mammalian epididymis. J Cell Physiol 2008;215:684-96. [CrossRef]

5. Arafa M, Agarwal A, Al Said S, Majzoub A, Sharma R, Bjugstad $\mathrm{KB}$, et al. Semen quality and infertility status can be identified through measures of oxidation-reduction potential. Andrologia 2018;50. [CrossRef]

6. Yao DF, Mills JN. Male infertility: lifestyle factors and holistic, complementary, and alternative therapies. Asian J Androl 2016;18:410-8. [CrossRef]

7. Sansone A, Di Dato C, de Angelis C, Menafra D, Pozza C, Pivonello R, et al. Smoke, alcohol and drug addiction and male fertility. Reprod Biol Endocrinol 2018;16:3. [CrossRef]

8. Ramlau-Hansen CH, Toft G, Jensen MS, Strandberg-Larsen $\mathrm{K}$, Hansen ML, Olsen J. Maternal alcohol consumption during pregnancy and semen quality in the male offspring: two decades of follow-up. Hum Reprod 2010;25:2340-5. [CrossRef]
9. Hansen ML, Thulstrup AM, Bonde JP, Olsen J, Hakonsen LB, Ramlau-Hansen $\mathrm{CH}$. Does last week's alcohol intake affect semen quality or reproductive hormones? A cross-sectional study among healthy young Danish men. Reprod Toxicol 2012;34:457-62. [CrossRef]

10. Kucheria K, Saxena R, Mohan D. Semen analysis in alcohol dependence syndrome. Andrologia 1985;17:558-63. [CrossRef]

11. Pajarinen JT, Karhunen PJ. Spermatogenic arrest and 'Sertoli cell-only' syndrome --common alcohol-induced disorders of the human testis. Int J Androl 1994;17:292-9. [CrossRef]

12. Muthusami KR, Chinnaswamy P. Effect of chronic alcoholism on male fertility hormones and semen quality. Fertil Steril 2005;84:919-24. [CrossRef]

13. Li Y, Lin H, Li Y, Cao J. Association between socio-psychobehavioral factors and male semen quality: systematic review and meta-analyses. Fertil Steril 2011;95:116-23. [CrossRef]

14. Jensen TK, Gottschau M, Madsen JO, Andersson AM, Lassen TH, Skakkebaek NE, et al. Habitual alcohol consumption associated with reduced semen quality and changes in reproductive hormones; a cross-sectional study among 1221 young Danish men. BMJ Open 2014;4:e005462. [CrossRef]

15. Condorelli RA, Calogero AE, Vicari E, La Vignera S. Chronic consumption of alcohol and sperm parameters: our experience and the main evidences. Andrologia 2015;47:368-79. [CrossRef]

16. Ghaffari MA, Rostami M. The effect of cigarette smoking on human sperm creatine kinase activity: as an ATP buffering system in sperm. Int J Fertil Steril 2013;6:258-65. https://www.ncbi.nlm. nih.gov/pmc/articles/PMC3850315/

17. Sofikitis N, Takenaka M, Kanakas N, Papadopoulos H, Yamamoto Y, Drakakis P, Miyagawa I. Effects of cotinine on sperm motility, membrane function, and fertilizing capacity in vitro. Urol Res 2000;28:370-5. [CrossRef]

18. İrez T, Ocal P, İdil M, Kaleli S, Uyar Y, Sahmay S, et al. Effects of smoking cigarette on intrauterine insemination outcomes. Basic Clin Sci 2013;2:20-4. [CrossRef]

19. Shenker NS, Ueland PM, Polidoro S, van Veldhoven K, Ricceri F, Brown R, et al. DNA methylation as a long-term biomarker of exposure to tobacco smoke. Epidemiology 2013;24:712-6. [CrossRef]

20. Cui X, Jing X, Wu X, Wang Z, Li Q. Potential effect of smoking on semen quality through DNA damage and the downregulation of Chk1 in sperm. Mol Med Rep 2016;14:753-61. [CrossRef]

21. Harlev A, Agarwal A, Gunes SO, Shetty A, du Plessis SS. Smoking and Male Infertility: An Evidence-Based Review. World J Mens Health 2015;33:143-60. [CrossRef]

22. Agarwal A, Majzoub A, Esteves SC, Ko E, Ramasamy R, Zini A. Clinical utility of sperm DNA fragmentation testing: practice recommendations based on clinical scenarios. Transl Androl Urol 2016;5:935-50. [CrossRef]

23. Loft S, Kold-Jensen T, Hjollund NH, Giwercman A, Gyllemborg J, Ernst E, et al. Oxidative DNA damage in human sperm influences time to pregnancy. Hum Reprod 2003;18:1265-72. [CrossRef]

24. Oyeyipo IP, Raji Y, Bolarinwa AF. Nicotine alters male reproductive hormones in male albino rats: The role of cessation. J Hum Reprod Sci 2013;6:40-4. [CrossRef]

25. Obembe OO, Olatoke TF, Atere TG. Reproductive Indices and Oxidative Stress Biomarkers of Male Wistar Rats Prenatally Exposed to Cigarette Smoke. Niger J Physiol Sci 2019;34:91-8. https://pubmed.ncbi.nlm.nih.gov/31449277/

26. Meri ZB, Irshid IB, Migdadi M, Irshid AB, Mhanna SA. Does cigarette smoking affect seminal fluid parameters? A comparative study. Oman Med J 2013;28:12-5. [CrossRef] 